\title{
Distribution of Aerobic Anoxygenic Phototrophs in Freshwater Plateau Lakes
}

\author{
Yingying Tian ${ }^{1,2}$, Xingqiang Wu', Qichao Zhou ${ }^{3}$, Oscar Omondi Donde ${ }^{1,2,4}$, \\ Cuicui Tian', Chunbo Wang ${ }^{1}$, Bing Feng ${ }^{1,2}$, Bangding Xiao ${ }^{1 *}$ \\ ${ }^{1}$ Key Laboratory of Algal Biology of Chinese Academy of Sciences, Institute of Hydrobiology, \\ University of Chinese Academy of Sciences, Wuhan 430072, China \\ ${ }^{2}$ University of Chinese Academy of Sciences, Beijing 100101, China \\ ${ }^{3}$ Yunnan Key Laboratory of Pollution Process and Management of Plateau Lake-Watershed, Yunnan Institute \\ of Environmental Science (Kunming China International Research Center for Plateau Lake), \\ Kunming 650034, China \\ ${ }^{4}$ Egerton University, Department of Environmental Science, P. O. Box 536-20115, Egerton-Kenya
}

Received: 13 February 2017

Accepted: 23 July 2017

\begin{abstract}
Aerobic anoxygenic phototrophic (AAP) bacteria are known functionally as photoheterotrophic microbes. Though numerously reported from ocean habitats, their distribution in freshwater lakes is far less documented. In the present study we investigated the dynamics of AAP bacteria in freshwater plateau lakes. Results revealed a high abundance of AAP bacteria in eutrophic lakes. Moreover, AAP bacteria were positively correlated with TN, TP, and $\mathrm{Chl} a$, but the variations of AAP bacterial proportion to potential total bacteria (AAPB\%). Alphaproteobacteria-related sequences dominated lakes Luguhu, Erhai, and Chenghai at ratios of 93.9, 85.4, and $70.6 \%$, respectively, and in total comprised eight clearly defined subgroups. Sequences affiliated with Beta- and Grammaproteobacteria were found to be rare taxa. Additionally, Alkalibacterium-like sequences belonging to Firmutes were assigned. Overall, sequences from Alpha-, Beta-, Gammaproteobacteria, and Firmutes separately comprised of 81.6, 8.8, 0.8, and 4.0\%. Our present work revealed extreme dynamics of AAP bacteria in both water columns and non-euphotic sediments of plateau aquatic ecosystems, which consolidated their wide distribution and enhanced adaptation.
\end{abstract}

Keywords: aerobic anoxygenic phototrophs, distribution, plateau freshwater lake

\section{Introduction}

Aerobic anoxygenic phototrophic (AAP) bacteria are photoheterotrophs that use both organic substrates

*e-mail: bdxiao@ihb.ac.cn; xqwu@ihb.ac.cn and solar light for carbon and energy requirements. The prevalence of AAP bacteria and their functional role in biogeochemical cycles were numerously reported in ocean habitats [1-4]. In most studies, they were defined as an important contributor to the carbon cycle. AAP bacteria could be approximately $<1 \%$ to $10 \%$ of total bacteria in the euphotic zones of marine environments $[1,4-6]$. The cell size of AAP bacteria was significantly larger than 
cell size for members of the bacterial assemblage, and the mean cell volume for AAP bacteria was $2.78 \pm 0.72$ times larger than that of mean biovolume of total bacteria [6]. In some coastal mesotrophic estuaries, AAP bacteria exceeded $10 \%$, which might be ascribed to the numerous particles in these environments [7-8]. In the South Pacific Ocean, the proportion of AAP bacteria was approximately $25 \%$ of total bacterioplankton, suggesting the potential contribution of other environmental variables [9].

Emerging findings indicate that AAP bacteria are ubiquitous in both eutrophic and oligotrophic environments [1-2, 10-11]. However, information on the AAP abundance that relates to the trophic status is inadequately recorded. Though research studies on AAP bacteria have been frequently reported [12-15], the distribution of AAP bacteria in specific areas remains unclearly and inadequately understood, e.g., freshwater plateau lakes. The populations of anoxygenic phototrophic bacteria are morphologically and physiologically diverse, indicating an adaptation to the local stratified environments [16]. Indeed, common species of AAP bacteria might be a cosmopolitan species with worldwide distribution that were abundant not only in the oligotrophic open ocean but also in eutrophic aquaculture areas [17]. Some uncertainty remains regarding the the composition of AAP communities from various aquatic habitats. Carefully designed experiments need to be conducted for a better understanding of this interesting group of bacteria.

Methods based on detecting fluorescent signals from bacteriochlorophyll (Bchl) a (e.g., infrared epifluorescence microscopic analysis and highperformance liquid chromatography) are inaccurate for determining bacterial abundance. Both environmental variables and physiological state of cell would influence the fluorescence signal [5]. Cases of environmental study mostly exploited the puf $\mathrm{M}$ gene (encoding the $\mathrm{M}$ subunit of the bacterial reaction center) as a convenient marker for anoxygenic phototrophs harboring type2 reaction centers [18]. As is known, this functional group harbors a diverse assembly of species that taxonomically belong to various subgroups of Alpha-, Beta- and Gammaproteobacteria. To gain knowledge of AAP bacteria in plateau regions of freshwater lake environments, experiments were conducted in Yunnan,
China. The trophic gradients offer a unique context to link nutrients, trophic status, and other environmental variables with AAP bacterial abundance.

The aim of this study was to clarify the distribution pattern of AAP bacteria in the freshwater plateau lakes. High specific and sensitive quantitative polymerase chain reaction (qPCR) assay was used to determine bacterial abundance. The retrieval of the $p u f \mathrm{M}$ gene from toxic water columns indicates the potential for photoheterotrophs to carry out aerobic anoxygenic photosynthesis. Though AAP bacteria are common in aquatic environments, the community structure that localizes especially non-euphotic sediments are rarely clarified. Clone libraries exploiting the $p u f \mathrm{M}$ gene were applied in this study. Indeed, this work helps to provide a better understanding of the distribution pattern of AAP bacteria in plateau lake environments.

\section{Materials and Methods}

\section{Description of the Study Sites}

Seven independent lakes at an average altitude of 2,000 $\mathrm{m}$ were investigated in Yunnan Province in southwestern China. Samples were collected in January 2015 (in winter). A man-made sluice gate that was put up in 1996 divides Lake Dianchi into two independent parts: Lake Caohai and Lake Waihai. In the present work, DC stands for Lake Waihai and $\mathrm{CH}$ represents Lake Caohai. The other five sampling sites were Lake Luguhu (LGH), Lake Fuxianhu (FXH), Lake Erhai (ErH), Lake Yangzonghai (YZH), and Lake Chenghai (ChH). Sample sites, geographic location, and types (from water and/or sediment) are shown in Table 1.

The trophic conditions of the determined lakes are well documented, especially in the Report on the State of the Environment of China. Based on the comprehensive nutrition state index $(\operatorname{TLI}(\Sigma))$, sampled lakes were grouped into oligotrophic lakes of LGH and FXH; mesotrophic lakes of $\mathrm{ErH}, \mathrm{ChH}$, and $\mathrm{YZH}$; and moderate eutrophic lakes of DC and $\mathrm{CH}$. The trophic status index (TLI) serves as a simple indicator that demonstrates the nutrients they receive at sampling. The function using TN is:

Table 1. Geographic coordinates and sample types of studied lakes.

\begin{tabular}{|c|c|c|c|}
\hline Station & Longitude & Latitude & Samples and Depth \\
\hline LGH & $100^{\circ} 46^{\prime} 33.78^{\prime \prime}$ & $27^{\circ} 42^{\prime} 29.16^{\prime \prime}$ & Water $0.5,5,10,20,30,50,80 \mathrm{~m}$; Sediment \\
\hline FXH & $102^{\circ} 53^{\prime} 38.27^{\prime \prime}$ & $24^{\circ} 32^{\prime} 15.52^{\prime \prime}$ & Water $(0.5,5,10,20,30,50,80 \mathrm{~m}$ \\
\hline $\mathrm{ErH}$ & $100^{\circ} 11^{\prime} 13.60^{\prime \prime}$ & $25^{\circ} 49^{\prime} 17.55^{\prime \prime}$ & Water $0.5,5,10,15,20 \mathrm{~m}$; Sediment \\
\hline $\mathrm{YZH}$ & $102^{\circ} 59^{\prime} 24.17^{\prime \prime}$ & $24^{\circ} 53^{\prime} 46.31^{\prime \prime}$ & Water $0.5,5,10,15 \mathrm{~m}$ \\
\hline $\mathrm{ChH}$ & $100^{\circ} 39^{\prime} 42.87^{\prime \prime}$ & $26^{\circ} 32^{\prime} 59.04^{\prime \prime}$ & Water $0.5,5,10,25 \mathrm{~m}$; Sediment \\
\hline $\mathrm{DC}$ & $102^{\circ} 43^{\prime} 12.43^{\prime \prime}$ & $24^{\circ} 51^{\prime} 19.18^{\prime \prime}$ & Water $0.5 \mathrm{~m}(\mathrm{DC} 4 \#, 14 \#, 22 \#)$ \\
\hline $\mathrm{CH}$ & $102^{\circ} 38^{\prime} 27.78^{\prime \prime}$ & $24^{\circ} 59^{\prime} 40.40^{\prime \prime}$ & Water $0.5 \mathrm{~m}(\mathrm{CH} 2 \#, 8 \#, 11 \#)$ \\
\hline
\end{tabular}


Table 2. Main physiochemical characteristics of lake water determined.

\begin{tabular}{|c|c|c|c|c|c|c|c|c|}
\hline Station & $\mathrm{WT}\left({ }^{\circ} \mathrm{C}\right)$ & $\mathrm{pH}$ & $\begin{array}{c}\mathrm{EC} \\
(\mathrm{mS} / \mathrm{cm})\end{array}$ & $\begin{array}{c}\mathrm{DO} \\
(\mathrm{mg} / \mathrm{L})\end{array}$ & $\begin{array}{c}\mathrm{Chl} a \\
(\mu \mathrm{g} / \mathrm{L})\end{array}$ & $\begin{array}{c}\mathrm{TN} \\
(\mathrm{mg} / \mathrm{L})\end{array}$ & $\begin{array}{c}\mathrm{TP} \\
(\mathrm{mg} / \mathrm{L})\end{array}$ & $\begin{array}{c}\mathrm{COD} \\
(\mathrm{mg} / \mathrm{L})\end{array}$ \\
\hline $\mathrm{LGH}$ & 10.0 & $8.33 \pm 0.32$ & $0.25 \pm 0.01$ & $6.74 \pm 2.28$ & $0.20 \pm 0.25$ & $0.19 \pm 0.06$ & $0.02 \pm 0.01$ & $1.11 \pm 0.19$ \\
\hline $\mathrm{FXH}$ & 13.8 & $8.34 \pm 0.01$ & $0.34 \pm 0.00$ & $6.94 \pm 0.45$ & $1.00 \pm 0.20$ & $0.22 \pm 0.07$ & $0.02 \pm 0.00$ & $1.22 \pm 0.52$ \\
\hline $\mathrm{ErH}$ & 11.5 & $8.71 \pm 0.02$ & $0.34 \pm 0.00$ & $7.71 \pm 0.37$ & $2.82 \pm 0.67$ & $1.32 \pm 0.08$ & $0.04 \pm 0.01$ & $3.58 \pm 0.24$ \\
\hline $\mathrm{YZH}$ & 13.7 & $8.27 \pm 0.03$ & $0.47 \pm 0.00$ & $7.97 \pm 0.72$ & $7.54 \pm 1.26$ & $0.72 \pm 0.09$ & $0.02 \pm 0.01$ & $3.30 \pm 0.13$ \\
\hline $\mathrm{ChH}$ & 14.5 & $9.51 \pm 0.01$ & $1.32 \pm 0.00$ & $7.63 \pm 0.24$ & $9.38 \pm 0.78$ & $0.93 \pm 0.08$ & $0.06 \pm 0.00$ & $5.92 \pm 0.36$ \\
\hline $\mathrm{DC}$ & 10.8 & $8.96 \pm 0.20$ & $0.42 \pm 0.01$ & $8.77 \pm 0.54$ & $49.48 \pm 5.85$ & $4.51 \pm 1.11$ & $0.07 \pm 0.03$ & $7.37 \pm 0.98$ \\
\hline $\mathrm{CH}$ & 10.6 & $8.06 \pm 0.08$ & $0.42 \pm 0.01$ & $5.36 \pm 0.25$ & $64.8 \pm 10.56$ & $9.90 \pm 0.11$ & $0.22 \pm 0.05$ & $7.41 \pm 1.07$ \\
\hline
\end{tabular}

$\mathrm{TLI}(\mathrm{TN})=10(5.453+1.694 \ln \mathrm{TN})$

\section{Sampling and Processing}

A Multi-Parameter Water Quality Sonde 6600 probe (Yellow Springs Instruments, Yellow Springs, USA) was used in deeper lakes (LGH, FXH, ChH, YZH, and ErH), while a Multi-Parameter Professional Plus probe (Yellow Springs Instruments, Yellow Springs, USA) was used in shallow lakes (DC and $\mathrm{CH}$ ). Physicochemical parameters such as $\mathrm{pH}$, conductivity (EC), dissolved oxygen (DO) concentration, water temperature (WT), and chlorophyll $a(\mathrm{Chl} a)$ were measured in situ, while total nitrogen (TN) and total phosphorus (TP) of lake water were measured by digestion using alkaline potassium peroxodisulfate or potassium peroxodisulfate. The results are presented in Table 2. DO concentrations in water columns were all above $6.65 \mathrm{mg} / \mathrm{L}$, except the $2.16 \mathrm{mg} / \mathrm{L}$ at the bottom layer of $80 \mathrm{~m}$ in Lake LGH. The DO in water columns revealed the toxic condition of these studied lakes.

Microbial samples were collected by filtering lake water of 100 to $300 \mathrm{~mL}$ through a $0.22-\mu \mathrm{m}$ pore-size polycarbonate filter (Millipore, Billerica, MA, USA). The frozen filters stored on ice were taken to the Institute of Hydrobiology in Wuhan, China. They were further lyophilized and carefully stored at $-20^{\circ} \mathrm{C}$ prior to the DNA extraction procedure. Sediments were kept frozen until analysis.

\section{Nucleic Acid Isolation and Amplification}

Environmental DNA was isolated using Water DNA Kit (Omega Bio-Tek, Norcross, GA, USA). A pufM 557F/750R primer set was used to amplify the fragment of puf $\mathrm{M}$ gene [19]. The primer pair 515F/806R [20] encoding V4 hypervariable region of 16S rRNA gene was used to identify total bacteria. PCR products were amplified using a Bio-Rad 100 ${ }^{\mathrm{TM}}$ PCR System (Bio-Rad Laboratories, Hercules, CA, USA). The amplification conditions consisted of denaturation of $94^{\circ} \mathrm{C}$ for $3 \mathrm{~min}$, followed by 40 cycles of $94^{\circ} \mathrm{C}$ for $30 \mathrm{~s}, 59^{\circ} \mathrm{C}$ for $30 \mathrm{~s}$, and $72^{\circ} \mathrm{C}$ for $1 \mathrm{~min}$, and a final extension at $72^{\circ} \mathrm{C}$ for $7 \mathrm{~min}$. All reaction mixtures contained $10 \mu \mathrm{L}$ of $2 \times$ Taq
MasterMix (CWBIO), $8.5 \mu \mathrm{L}$ of sterilized water, $0.5 \mu \mathrm{L}$ of $\mathrm{F} / \mathrm{R}$ primer $(10 \mathrm{pmol})$, and $0.5 \mu \mathrm{L}$ of template DNA.

\section{Clone Libraries of pufM Gene}

Each library was generated from a pool of three reaction mixtures. The PCR products were used as the insert DNA and gel-purified using an Axygen PCR Purification Kit (Corning, New York, USA). A reaction volume of $20 \mu \mathrm{L}$ was used for ligation procedures. It contained $8 \mu \mathrm{L}$ of DNA, $2 \mu \mathrm{L}$ of pMD18-T, and $10 \mu \mathrm{L}$ of solution I. Three independent clone libraries of $\mathrm{ChH}$, $\mathrm{ErH}$, and LGH of puf $\mathrm{M}$ gene were constructed according to Jiang et al. (2007) [12]. All of the clone libraries were screened for inserts by colony PCR and checked by gel electrophoresis. Amplification was carried out with 39 cycles at $94^{\circ} \mathrm{C}$ for $30 \mathrm{~s}, 55^{\circ} \mathrm{C}$ for $30 \mathrm{~s}$, and $72^{\circ} \mathrm{C}$ for $30-90$ s. Approximately 30 to 50 colonies per sample were sequenced using an ABI 3730x1 DNA analyzer. The nucleotide sequences were trimmed and assembled using BioEdit software. Sequences showing 97\% similarity or higher were considered to be from the same operational taxonomic unit (OTU). Shannon diversity indices of the clone libraries were calculated at the group level using Mothur project software (mothur.org/wiki/Mothur manual). Coverage (C) was calculated as follows: $\mathrm{C}=$ $1-(\mathrm{n} 1 / \mathrm{N})$, where $\mathrm{n} 1$ is the number of phylotypes that occurred only once in the clone library and $\mathrm{N}$ is the total number of analyzed clones. The sequences retrieved in this study were deposited in the database of GenBank under the accession numbers: KU533471-KU533503 (ChH1-ChH33), KU533504-KU533554 (LGH1-LGH51), and KU562968-KU563008 (ErH1-ErH41).

\section{Real-Time Quantitative PCR}

From all the water samples, copy numbers of $p u f \mathrm{M}$ gene and 16S rRNA gene were determined using qPCR assay. To generate a qPCR standard curve, a rightinserted clone was grown in LB medium. Plasmid DNA was extracted using the Axygen Plasmid Miniprep Kit (Axygen Biosciences, CA, USA) and further digested using the Aat II enzyme. Purification was performed by gel electrophoresis. The retrieved DNA product was used 
to yield a standard curve by serial dilution covering six orders from $10^{3}$ to $10^{8}$ copies of the templates per assay. The $10-\mu \mathrm{L}$ reaction mixture contained $5 \mu \mathrm{L}$ of Syber Green Master Mix (Bio-Rad Laboratories, Hercules, CA, USA), $0.5 \mu \mathrm{L}$ of each primer (10 pmol), $0.5 \mu \mathrm{L}$ of template, and $3.5 \mu \mathrm{L}$ of sterilized water. The amplification conditions of $\mathrm{puf} \mathrm{M}$ gene were $95^{\circ} \mathrm{C}$ for $3 \mathrm{~min}$, followed by 39 cycles $\left(15 \mathrm{~s}\right.$ at $94^{\circ} \mathrm{C}, 59^{\circ} \mathrm{C}$ for $30 \mathrm{~s}$, and $72^{\circ} \mathrm{C}$ for $30 \mathrm{~s}$ ), while conditions of $16 \mathrm{~S}$ rRNA gene were at $95^{\circ} \mathrm{C}$ for $3 \mathrm{~min}$, followed by 39 cycles $\left(15 \mathrm{~s}\right.$ at $94^{\circ} \mathrm{C}, 58^{\circ} \mathrm{C}$ for $30 \mathrm{~s}$, and $72^{\circ} \mathrm{C}$ for $\left.30 \mathrm{~s}\right)$. All of the qPCR reactions were performed in triplicate. Amplification efficiencies of $90-107.3 \%$ were obtained with $R^{2}$ values of 0.968 to 0.980 . Melting curve analysis always presents a single peak, indicating specific amplification of the target gene.

\section{Statistical Analysis}

Statistical analysis was conducted using the SPSS 20.0 software package. One-way analysis of variance (ANOVA) (LSD test) and independent-sample $\mathrm{T}$ test at the confidence level of 0.95 were used to test the differences between group mean values. A two-tailed Pearson correlation analysis was conducted to illustrate the correlative relationships between environmental variables and bacterial abundances. Redundancy analysis (RDA) was applied to find the environmental predictors that best explained the distribution of AAP bacteria and samples. These analyses were performed using CANOCO version 4.5 .

\section{Results and Discussion}

\section{Abundances of pufM Gene}

As shown in Fig. 1, numbers of 16S rRNA gene enhanced with the nutrient contents and the copy numbers ranged from $10^{7}$ to $10^{9} \mathrm{~mL}^{-1}$ of water; copies of

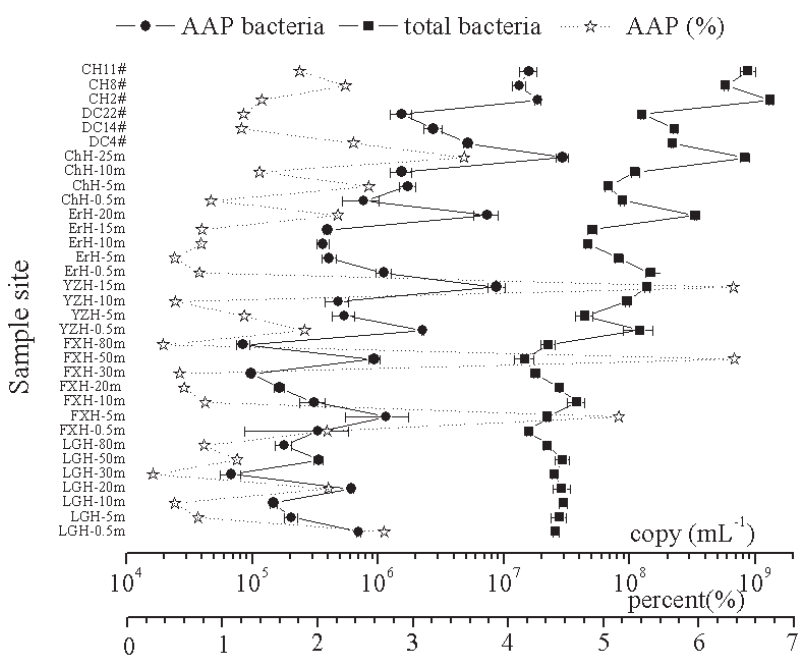

Fig. 1 Abundances of AAP bacteria and total bacteria and proportion of AAP bacteria to total bacteria (AAP\%). puf $\mathrm{M}$ gene varied from $10^{5}$ to $10^{7} \mathrm{~mL}^{-1}$ and followed the nutrient conditions as well. In detail, numbers of puf $\mathrm{M}$ gene were $3.80( \pm 3.39) \times 10^{5} \mathrm{~mL}^{-1}$ in the oligotrophic lakes, $2.15( \pm 2.85) \times 10^{6}$ in the mesotrophic lakes (exclude $2.93( \pm 0.33) \times 10^{7}$ of $\mathrm{ChH}-25 \mathrm{~m}$, bottom water layer), and $3.16( \pm 1.86) \times 10^{6}$ and $1.59( \pm 0.27) \times 10^{7}$ from eutrophic lakes $\mathrm{DC}$ and $\mathrm{CH}$, respectively. Analysis on the vertical distribution of AAP bacteria confirmed their presence in the upper parts of the water column with minimum numbers in the anoxic bottom waters [13]. This study showed a varied vertical distribution of AAP bacteria. For instance, it presented a marked increase of bottom waters of lakes $\mathrm{ChH}$ and $\mathrm{ErH}$, while no significant difference was found in LGH between sampled depths. A simple regression analysis showed a good linear relationshipship between AAP bacteria and total bacteria $\left(R^{2}=0.80, \mathrm{~N}=33, P<0.001\right)$ against the copy numbers at a ratio of $1.75( \pm 1.58) \%$. This signaled that AAP bacterial proportion to total bacteria (AAP\%) was not clearly dependent on nutrients of phosphate or nitrogen. The RDA model accounted for $94 \%$ of the variations in bacterial abundance. The first two axes explained up to $55.3 \%$ (axis 1) and 39.1\% (axis 2) of the variations. The variables that correlated most strongly with these axes were TN, TP, Chl $a$, and TLI (TN). Numbers of puf $\mathrm{M}$ gene and 16S rRNA gene appeared remarkably well correlated with indices of TN, TP, Chl $a$, and TLI (TN), whereas AAP\% was closer but not significant to EC and WT as shown in Fig. 2. Pearson correlation analysis revealed that the abundances of $p$ u $\mathrm{M}$ gene were remarkably correlated with 16S rRNA gene $(\mathrm{r}=0.893, \mathrm{~N}=33, P<0.001), \mathrm{TP}(\mathrm{r}=0.658$, $\mathrm{N}=33, P<0.001), \mathrm{TN}(\mathrm{r}=0.589, \mathrm{~N}=33, P<0.01), \mathrm{TLI}(\mathrm{TN})$ $(\mathrm{r}=0.551, \mathrm{~N}=33, P=0.001), \mathrm{Chl} a(\mathrm{r}=0.532, \mathrm{~N}=30$, $P=0.002)$, and total COD $(\mathrm{r}=0.497, \mathrm{~N}=33, \mathrm{P}=0.003)$. Water depth neither contributed to the bacterial abundance nor influenced AAP\%. Nutrient loads calculated by TN, TP, and total COD were significantly correlated, e.g., $\mathrm{TN}$ and TP $(\mathrm{r}=0.918, \mathrm{~N}=33, P<0.001)$ and total COD (r $=0.489, \mathrm{~N}=33, P=0.004)$.

The high abundance of $p u f \mathrm{M}$ gene from eutrophic DC and $\mathrm{CH}$ was consistent with the previous study by Shi et al. [14] on eutrophic lakes Taihu and Chaohu in China. Result showed that free-living AAP bacteria were separately $2.3( \pm 0.69) \times 10^{6}$ cells $\mathrm{mL}^{-1}$ in Lake Taihu and $1.3( \pm 0.29) \times 10^{5}$ cells $\mathrm{mL}^{-1}$ in Lake Chaohu, which was higher than the previously reported levels in other eutrophic freshwater bodies [14]. The abundance of AAP bacteria was highly variable with copies of $p u f \mathrm{M}$ gene ranging from $1.1 \times 10^{2}$ to $1.4 \times 10^{5} \mathrm{~mL}^{-1}$ [21] and 0.3 to $12.04 \times 10^{5}$ cells $\mathrm{mL}^{-1}$ in the surface layers of peat-bog lakes by epifluorescence microscopy numbering [13].

Abundances of AAP bacteria positively correlated with chlorophyll $a$ concentrations in a variety of water bodies [3, 22-23], suggesting that primary productivity may contribute to the abundance of AAP bacteria. Annotated gene content revealed the dependence of incertae sedis Hyphomonadaceae strain UKL13-1 and incertae sedis Betaproteobacterium strain UKL13-2 on carbon and nitrogen fixation from Aphanizomenon 


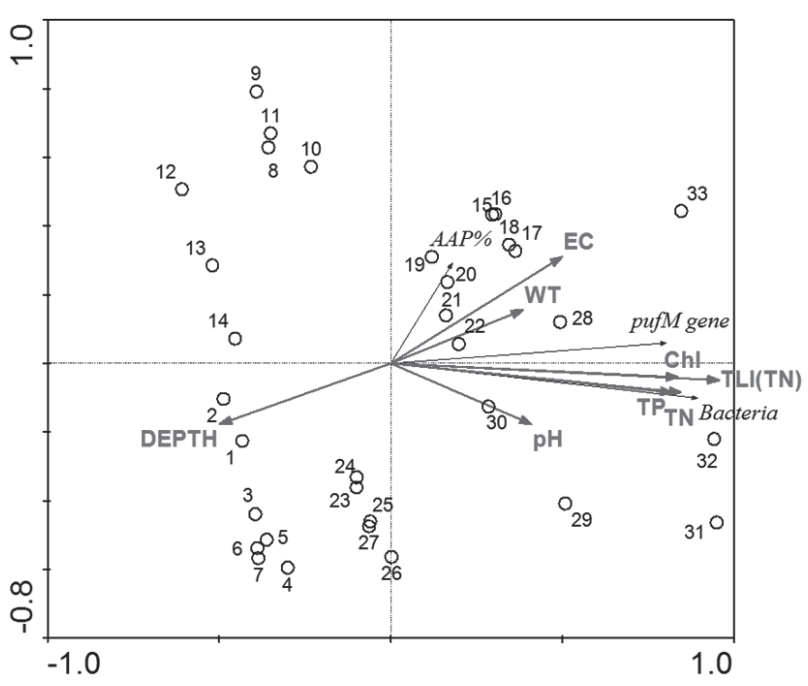

Fig. 2. Ordination plot of redundancy analysis (RDA) for puf $\mathrm{M}$ gene, 16S rRNA gene (total bacteria), and AAP\% (species) with hydrochemical data (environmental variables) for studied lakes. Numbers are the sampling sites: 1-7, LGH-0.5, 5, 10, 20, 30, 50, $80 \mathrm{~m} ; 8-14$, FXH-0.5, 5, 10, 20, 30, 50, $80 \mathrm{~m}$; 15-18, ChH-0.5, $5,10,25 \mathrm{~m} ; 19-22$, YZH-0.5, 5, 10, $15 \mathrm{~m} ; 23-27$, ErH-0.5, 5, 10, 15, $20 \mathrm{~m}$; and 28-33, DC4\#, 14\#, 22\#, CH2\#, 8\#, 11\#.

flos-aquae [24]. In addition, responses of AAP bacteria to algal blooms were suggested to be algae-species specific and somewhat independent of chlorophyll $a$ concentration [25]. But whether the relationship reflects the direct association with primary producers or the same dependence on limiting nutrients such as phosphate or nitrogen is still not clear [18].

Factors relating to the distribution of AAP bacteria are diverse. In ultra-oligotrophic cold high mountain lakes (Central Pyrenees, Spain), no significant relationship was found between the richness/diversity of AAP bacteria and any measured limnological characteristics or trophic status, but a negative correlation with ammonia concentration [26]. AAP bacteria of 0.16 to $7.9 \times 10^{4}$ cells $\mathrm{mL}^{-1}$ in coastal and continental shelf waters was higher than in oceanic waters in the East China Sea (in 04, 200209, 2003) [22]. Although there is no enhanced tendency of AAP bacteria in getting attached to particles as compared to heterotroph species, metabolically active AAP bacteria may benefit from the nutrient-rich microenvironment in the particles. Moreover, the particle-attached lifestyle may also provide protection against grazing [18].
Even though large rivers are commonly segregated by damming, it was not clear whether reservoirs explained the spatial dynamics of AAP bacteria as documented by Ruiz-Gonzalez et al. (2013) [27]. In addition, salinity and $\mathrm{pH}$ were also potential factors regulating AAP bacterial diversity and community composition [12]. Analysis demonstrated that AAP bacteria prefer $\mathrm{pH}$-neutral lakes (between 6.7 and 7.6) with higher conductivity [13]. The suitable light conditions, nutrient supply, and sufficient oxygen from cyanobacteria were postulated to favor the growth of AAP bacteria, but this postulation needs further careful study.

\section{Diversity of $p u f \mathrm{M}$ gene populations}

For this study, 33, 41, and 51 sequences were separately retrieved from the clone libraries of $\mathrm{ChH}, \mathrm{ErH}$, and LGH. Parameters of $\mathrm{pH}, \mathrm{TP}, \mathrm{TN}$, organic matters $(\mathrm{OM})$, total organic carbon (TOC) numbers of OUT, and indices of CHAO, ACE, and SHANNON are shown in Table 3. Sediments of ErH and LGH were similar in the values of $\mathrm{pH}, \mathrm{OM}, \mathrm{TOC}$, OUT, and SHANNON index, whereas $\mathrm{ChH}$ was relatively different. The number of OTUs in each library was ranked as follows: $\mathrm{ChH}(13)<\mathrm{ErH}$ (19) $<$ LGH (23). The richness (by CHAO and ACE) was ordered as: $\mathrm{ChH}<\mathrm{ErH}<\mathrm{LGH}$, while for diversity (by SHANNON) it was $\mathrm{ChH}<\mathrm{LGH}<\mathrm{ErH}$.

All the sequences attained were online blasted and summarized in Table 4. Overall, sequences from Alpha-, Beta-, Gammaproteobacteria, and Firmutes separately comprised $81.6,8.8,0.8$, and $4.0 \%$. This demonstrated that AAP photoheterotrophs in sediments were mostly related to Alphaproteobacteria, and it consisted of up to $93.9,85.4$, and $70.6 \%$ in libraries of $\mathrm{ChH}, \mathrm{ErH}$, and $\mathrm{LGH}$, respectively. AAP bacteria close to Methylobacterium-, Bosea-, Bradyrhizobium-, Rhodobacter-, Alkalibacterium-, Rubritepida-, Rubrivivax-, Sphingomonas-, Limnohabitans-, and Roseococcus-like AAPs were involved, among which rare species were Allochromatium-like Gammaproteobacteria (one sequence), Hydrogenophaga-like (one sequence) and Limnohabitans-like (two sequences) Betaproteobacteria, and Roseococcus-like Alphaproteobacteria (two sequences). In addition, five other sequences from Alkalibacterium-like bacteria were assigned, which were not the known taxonomic AAP bacteria but might

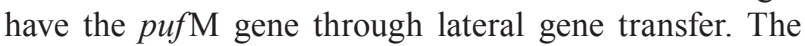
composition of AAP populations from geographically

Table 3. Main physiochemical and biological characteristics of sediments determined.

\begin{tabular}{|c|c|c|c|c|c|c|c|c|c|c|}
\hline Station & $\mathrm{pH}$ & $\begin{array}{c}\mathrm{TP} \\
(\mathrm{mg} / \mathrm{g})\end{array}$ & $\begin{array}{c}\mathrm{TN} \\
(\mathrm{mg} / \mathrm{g})\end{array}$ & $\begin{array}{c}\text { OM } \\
(\%)\end{array}$ & $\begin{array}{c}\text { TOC } \\
(\%)\end{array}$ & $\mathrm{C}$ & OTU & ACE & CHAO & SHANNON \\
\hline $\mathrm{ChH}$ & 8.48 & $2.19 \pm 0.10$ & 3.45 & $9.78 \pm 0.94$ & 3.47 & 0.74 & $13(11)$ & 27.20 & 23.14 & 3.16 \\
\hline $\mathrm{ErH}$ & 7.76 & $3.08 \pm 0.05$ & 6.81 & $14.84 \pm 1.57$ & 6.24 & 0.67 & $19(12)$ & 38.45 & 38.00 & 3.62 \\
\hline $\mathrm{LGH}$ & 7.80 & $6.67 \pm 0.62$ & 6.05 & $16.99 \pm 1.95$ & 5.94 & 0.71 & $23(18)$ & 45.82 & 44.50 & 3.52 \\
\hline
\end{tabular}

Numbers in bracket are unique OTUs. 
Table 4. BLAST analysis of all of the sequences in the puf $\mathrm{M}$ gene clone libraries and percentages of clones belonging to different types of AAP bacteria in each $p u f \mathrm{M}$ gene clone library according to BLAST analysis of the $p u f \mathrm{M}$ genes.

\begin{tabular}{|c|c|c|c|c|c|c|}
\hline \multirow{2}{*}{ Nearest relative } & \multirow{2}{*}{$\begin{array}{l}\text { Accession } \\
\text { number }\end{array}$} & \multirow{2}{*}{ Taxon $^{\mathrm{a}}$} & \multicolumn{4}{|c|}{ Number of clones and their percentage of different types of AAP bacteria } \\
\hline & & & Total & $\mathrm{ChH}$ & $\mathrm{ErH}$ & LGH \\
\hline \multirow{2}{*}{ Methylobacterium } & AP01475 & \multirow{2}{*}{ Alpha- } & $29(23.2)$ & $8(24.2)$ & $12(29.3)$ & $9(17.6)$ \\
\hline & СР001001 & & $6(4.8)$ & 0 & $1(2.4)$ & $5(9.8)$ \\
\hline \multirow{2}{*}{ Bradyrhizobium } & AP012279 & \multirow{2}{*}{ Alpha- } & $13(10.4)$ & $8(24.2)$ & 0 & $5(9.8)$ \\
\hline & СР000494 & & $1(0.8)$ & 0 & 0 & $1(2.0)$ \\
\hline Rubritepida & AY064409 & Alpha- & $12(9.6)$ & $8(24.2)$ & $4(9.8)$ & 0 \\
\hline \multirow{2}{*}{ Bosea } & CP016464 & \multirow{2}{*}{ Alpha- } & $15(12.0)$ & $1(3.0)$ & $7(17.1)$ & $7(13.7)$ \\
\hline & KC465427 & & $4(3.2)$ & 0 & $1(2.4)$ & $3(5.9)$ \\
\hline Rhodovulum & KP212380 & Alpha- & $8(6.4)$ & 0 & $8(19.5)$ & 0 \\
\hline Rubrivivax & AH012710 & Beta- & $8(6.4)$ & 0 & $4(9.8)$ & $4(7.8)$ \\
\hline \multirow{2}{*}{$\begin{array}{c}\text { Rhodobacter/ } \\
\text { Rhodobacteraceae }\end{array}$} & HE966451 & Alpha- & $6(4.8)$ & $6(18.2)$ & 0 & 0 \\
\hline & EU009369 & Alpha- & $1(0.8)$ & 0 & 0 & $1(2.0)$ \\
\hline Sphingomonas & CP010836 & Alpha- & $4(3.2)$ & 0 & $2(4.9)$ & $2(3.9)$ \\
\hline Alkalibacterium & EU196352 & Firmutes & $5(4.0)$ & $1(3.0)$ & $1(2.4)$ & $3(5.9)$ \\
\hline Allochromatium & CP001896 & Gamma- & $1(0.8)$ & 0 & $1(2.4)$ & 0 \\
\hline Hydrogenophaga & СР016449 & Beta- & $1(0.8)$ & 0 & 0 & $1(2.0)$ \\
\hline Limnohabitans & KM659111 & Beta- & $2(1.6)$ & 0 & 0 & $2(3.9)$ \\
\hline Roseococcus & AY064410 & Alpha- & $2(1.6)$ & 0 & 0 & $2(3.9)$ \\
\hline Alphaproteobacterium & AF393993 & Alpha- & $1(0.8)$ & 0 & 0 & $1(2.0)$ \\
\hline Proteobacterium & GU080266 & undefined & $3(2.4)$ & 0 & 0 & $3(5.9)$ \\
\hline Arctic spring bacterium & EU196298 & undefined & $3(2.4)$ & $1(3.0)$ & 0 & $2(3.9)$ \\
\hline \multicolumn{3}{|c|}{ Summary } & \multicolumn{4}{|c|}{ Percentage (\%) } \\
\hline \multicolumn{3}{|c|}{ Alpha- } & 81.6 & 93.9 & 85.4 & 70.6 \\
\hline \multicolumn{3}{|c|}{ Beta- } & 8.8 & 0 & 9.8 & 13.7 \\
\hline \multicolumn{3}{|c|}{ Gamma- } & 0.8 & 0 & 2.4 & 0 \\
\hline \multicolumn{3}{|c|}{ Firmutes } & 4.0 & 3.0 & 2.4 & 5.9 \\
\hline
\end{tabular}

${ }^{a}$ Alpha, Beta, and Gamma designations refer to the subclasses of proteobacteria.

distant lakes were easily subject to be different. The unique OTUs in each library informed us of the complex interplay of local contemporary environmental effects and dispersal limitations.

AAP populations in the non-euphotic sediments improve our knowledge on the habitats and communal structures of AAP bacteria in these specific locations. It helps to clarify that AAP bacteria are not strictly restrained within the euphotic layer in surface water. Previous work documented that AAP bacteria of Alphaproteobacteria were present in both water samples and sediments at ratios of $25.7 \%$ and $27.8 \%$ of all puf $\mathrm{M}$ sequences derived from shrimp ponds [28]. The dark condition promoted the accumulation of BChl [29]. Results indicated that dark culture condition was required for the enlargement of spheroplasts of Erythrobacter litoralis and known marine AAP bacterium, and the enlargement was inhibited under continuous light [30].

The survey of AAP consortia at the Tibetan Plateau found that saline water Gammaproteobacteria-like AAP bacterial sequences dominated the water [15]. Obviously, it was quite different from the communal structures of AAP bacteria in sediments in our study. In our work, results indicated that Methylobacterium-, Rhodovulum-, and Bosea-like AAP bacteria dominated at a ratio of up to $68.3 \%$ of total AAP sequences. Two possibilities explain the retrieval of AAP sequences in sediments: either that they are derived from fossil DNA originating from dead AAP bacterial cells deposited from the overlaying water column or they are indeed active cells that contain photosynthesis genes. It is not rare that specific kinds 
of microorganisms always occur once their habitat requirements are met. Exploiting the Winogradsky column, rare taxa were highly enriched [31]. This supports the hypothesis that rare taxa serve as a microbial seed bank and can be abundant under appropriate environmental conditions. These appearances of rare microbes in environments can be explained by the sheer number of microbial cells occurring on Earth and high efficiencies of dispersal, but low probabilities of local extinction, which perhaps represents a kind of "biological detritus" in various resting states [32]. The possibilities of lateral gene transfer might explain the retrieval of five sequences harboring photosynthetic operons assigned to Alkalibacterium-like bacteria from Firmutes phylum. Gene acquisition might provide these non-phototrophic microorganisms with increased adaptive fitness [33]. Currently, isolates of AAP bacteria in this phylum have not been reported. Recently, Gemmatimonas phototrophica was found to harbor a photosynthesis gene cluster of proteobacterial origin [34-35] and phototrophic Gemmatimonadetes bacteria consisting of $0.4-11.9 \%$ of whole phototrophic microbial communities in their habitats [36].

The habitats for AAP bacteria are as diverse as marine environments, freshwater lakes, saline lakes, soda lakes, and soils [37-40]. The complex interplay of local contemporary environmental effects and dispersal limitations contribute to the distribution of anoxygenic phototrophs. Covering a wide latitudinal gradient, results suggest that the distribution patterns of freshwater AAP bacteria are likely driven by a combination of small-scale environmental conditions (specific to each lake and region) and large-scale geographic factors (climatic regions across a latitudinal gradient) [41]. Alphaproteobacteria-related sequences had a broader phylogenetic diversity. Sphingomonas- and Rhodobacterlike bacteria dominated lakes with alkaline to neutral $\mathrm{pH}$, whereas Methylobacterium-related sequences dominated the AAP community in the acidic and humic matter-rich basin of Lake Grosse Fuchskuhle [42]. In the present work, sediments with $\mathrm{pH}$ of 7.76-8.48 and TOC contents of 3.47$6.24 \%$ Methylobacterium-like AAP bacteria dominated at a ratio of $56 \%$ of all AAP assemblages. It seemed that Alphaproteobacteria-related sequences were extremely diverse, harboring 8 subgroups at least. Commonly, open ocean environments tend to be homogeneous on a large scale, while soils and sediments are heterogeneous on a large scale [33]. The variable AAP communal structure may reflect the potential of AAP bacteria to cope with the environmental conditions of freshwater ecosystems.

Today, more and more novel aerobic anoxygenic strains are isolated. Most of the isolates are non-phototrophic but all exclusively belonging to Alphaproteobacteria. From surface soil, three strains (PB56 ${ }^{\mathrm{T}}, \mathrm{PB} 180$, PB229) containing the genes of $p u f \mathrm{LM}$ were isolated. The higher $\mathrm{G}+\mathrm{C}$ content, absence of straight-chain 2-hydroxy fatty acids, and phylogenetic distances from all established species of the genus Sphingomonas distinguish them as a novel lineage among the Sphingomonadaceae
[43]. The occurrence of anoxygenic phototrophs in biological soil crusts implies a higher efficiency of light harvesting by soil crust organisms than previously realized. Methylobacterium, Belnapia, Muricoccus, and Sphingomonas made up the aerobic anoxygenic communities based on 16S rRNA gene sequences [40]. Furthermore, the production of extracellular adhesives and holdfast structures by several AAP bacteria implicates this functional group as potential key players in physically stabilizing loose sandy soils [29]. The utility of near-infrared radiation accelerated turnover of soil organic carbon content; indeed, AAP bacteria derive up to $15-20 \%$ of their cellular energy from light [4]. A better understanding of the evolutionary origin, physiological properties, and biological roles of AAP bacteria in the biosphere depend on the continuing studies of the existing species and isolation of new strains.

\section{Conclusions}

Dependency on nutrients is a potential engine that drives the distribution of AAP bacteria. They were most abundant in the eutrophic lake and were significantly correlated with TN, TP, Chl $a$, and trophic status. However, no clear correlative relationship between AAP $\%$ and nutrients was observed. The diverse AAP bacteria in non-euphotic sediments demonstrate the wide distribution of AAP photoheterotrophs. The mechanism that AAP bacteria have developed to cope with the noneuphotic conditions should be paid more attention.

\section{Acknowledgements}

This work was supported by the National Natural Science Foundation of China (grant Nos. 31370504 and 31670465); the Joint NSFC-ISF Research Program, jointly funded by the National Natural Science Foundation of China and the Israel Science Foundation (grant No. 41561144008); and the Major Science and Technology Program for Water Pollution Control and Treatment of China (grant No. 2013ZX07102005).

\section{References}

1. COTTRELL M.T., MANNINO A., KIRCHMAN D.L. Aerobic anoxygenic phototrophic bacteria in the MidAtlantic Bight and the North Pacific Gyre. Appl. Environ. Microbiol. 72 (1), 557, 2006.

2. SCHWALBACH M.S., FUHRMAN J.A. Wide-ranging abundances of aerobic anoxygenic phototrophic bacteria in the world ocean revealed by epifluorescence microscopy and quantitative PCR. Limnol. Oceanogr. 50 (2), 620, 2005.

3. RITCHIE A.E., JOHNSON Z.I. Abundance and genetic diversity of aerobic anoxygenic phototrophic bacteria of coastal regions of the Pacific Ocean. Appl. Environ. Microbiol. 78 (8), 2858, 2012. 
4. KOLBER Z.S., PLUMLEY F.G., LANG A.S., BEATTY J.T., BLANKENSHIP R.E., VANDOVER C.L., VETRIANI C., KOBLIZEK M., RATHGEBER C., FALKOWSKI P.G. Contribution of aerobic photoheterotrophic bacteria to the carbon cycle in the ocean. Science, 292 (5526), 2492, 2001.

5. KOLBER Z.S., VAN DOVER C., NIEDERMAN R., FALKOWSKI P. Bacterial photosynthesis in surface waters of the open ocean. Nature, 407 (6801), 177, 2000.

6. SATO-TAKABE Y., SUZUKI S., SHISHIKURA R., HAMASAKI K., TADA Y., KATAOKA T., YOKOKAWA T., YOSHIE N., SUZUKI S. Spatial distribution and cell size of aerobic anoxygenic phototrophic bacteria in the Uwa Sea, Japan. J. Oceanogr. 71 (1), 151, 2014.

7. LAMIR., CUPEROAZ., RAS J., LEBARON P., KOBLÍZEK M. Distribution of free-living and particle-attached aerobic anoxygenic phototrophic bacteria in marine environments. Aquat. Microb. Ecol. 55 (1), 31, 2009.

8. COTTRELL M.T., RAS J., KIRCHMAN D.L. Bacteriochlorophyll and community structure of aerobic anoxygenic phototrophic bacteria in a particle-rich estuary. ISME J. 4 (7), 945, 2010.

9. LAMI R., COTTRELL M.T., RAS J., ULLOA O., OBERNOSTERER I., CLAUSTRE H., KIRCHMAN D.L., LEBARON P. High abundances of aerobic anoxygenic photosynthetic bacteria in the South Pacific Ocean. Appl. Environ. Microbiol. 73 (13), 4198, 2007.

10. LEHOURS A.C., COTTRELL M.T., DAHAN O., KIRCHMAN D.L., JEANTHON C., Summer distribution and diversity of aerobic anoxygenic phototrophic bacteria in the Mediterranean Sea in relation to environmental variables. FEMS Microbiol. Ecol. 74(2), 397, 2010.

11. SIERACKI M.E., GILG I.C., THIER E.C., POULTON N.J., GOERICKE R. Distribution of planktonic aerobic anoxygenic photoheterotrophic bacteria in the northwest Atlantic. Limnol. Oceanogr. 51 (1), 38, 2006.

12. JIANG H., DONG H., YU B., LIU X., LI Y., JI S., ZHANG C.L. Microbial response to salinity change in Lake Chaka, a hypersaline lake on Tibetan plateau. Environ. Microbiol. 9 (10), 2603, 2007.

13. LEW S., LEW M., KOBLÍŽEK M. Influence of selected environmental factors on the abundance of aerobic anoxygenic phototrophs in peat-bog lakes. Environ. Sci. Pollut. R. 23 (14), 13853, 2016.

14. SHI L., CAI Y., CHEN Z., ZHOU Y., LI P., KONG F. Diversity and abundance of aerobic anoxygenic phototrophic bacteria in two cyanobacterial bloom-forming lakes in China. Int. J. Lim. 46 (4), 233, 2010.

15. JIANG H., DONG H., YU B., LV G., DENG S., WU Y., DAI M., JIAO N. Abundance and diversity of aerobic anoxygenic phototrophic bacteria in saline lakes on the Tibetan plateau. FEMS Microbiol. Ecol. 67 (2), 268, 2009.

16. YURKOVA N., RATHGEBER C., SWIDERSKI J., STACKEBRANDT E., BEATTY J.T., HALL K.J., YURKOV V. Diversity, distribution and physiology of the aerobic phototrophic bacteria in the mixolimnion of a meromictic lake. FEMS Microbiol. Ecol. 40 (3), 191, 2002.

17. SATO-TAKABE Y., NAKAO H., KATAOKA T., YOKOKAWA T., HAMASAKI K., OHTA K., SUZUKI S. Abundance of common aerobic anoxygenic phototrophic bacteria in a coastal aquaculture area. Front. Microbiol. 7, 1996, 2016

18. KOBLIZEK M. Ecology of aerobic anoxygenic phototrophs in aquatic environments. FEMS Microbiol. Rev. 39 (6), 854, 2015.
19. ACHENBACH L.A., CAREY J., MADIGAN M.T. Photosynthetic and phylogenetic primers for detection of anoxygenic phototrophs in natural environments. Appl. Environ. Microbiol. 67 (7), 2922, 2001.

20. CAPORASO J.G., LAUBER C.L., WALTERS W.A., BERG-LYONS D., LOZUPONE C.A., TURNBAUGH P.J., FIERER N., KNIGHT R. Global patterns of 16S rRNA diversity at a depth of millions of sequences per sample. P. Nat. Acad. Sci. 108 (Supplement 1), 4516, 2011.

21. BIBILONIISAKSSON J., SEYMOUR J., INGLETON T., VAN D.K.J., BODROSSY L., BROWN M. Spatial and temporal variability of aerobic anoxygenic photoheterotrophic bacteria along the east coast of Australia. Environ. Microbiol. 2016.

22. ZHANG Y., JIAO N. Dynamics of aerobic anoxygenic phototrophic bacteria in the East China Sea. FEMS Microbiol. Ecol. 61 (3), 459, 2007.

23. HOJEROVA E., MASIN M., BRUNET C., FERRERA I., GASOL J.M., KOBLIZEK M. Distribution and growth of aerobic anoxygenic phototrophs in the Mediterranean Sea. Environ. Microbiol. 13 (10), 2717, 2011.

24. DRISCOLL C.B., OTTEN T.G., BROWN N.M., DREHER T.W. Towards long-read metagenomics: complete assembly of three novel genomes from bacteria dependent on a diazotrophic cyanobacterium in a freshwater lake coculture. Stand. Genomic Sci. 12, 9, 2017.

25. CHEN Y., ZHANG Y., JIAO N. Responses of aerobic anoxygenic phototrophic bacteria to algal blooms in the East China Sea. Hydrobiologia, 661 (1), 435, 2010.

26. CALIZ J., CASAMAYOR E.O. Environmental controls and composition of anoxygenic photoheterotrophs in ultraoligotrophic high-altitude lakes (Central Pyrenees). Env. Microbiol. Rep. 6 (2), 145, 2014.

27. RUIZ-GONZALEZ C., PROIA L., FERRERA I., GASOL J.M., SABATER S. Effects of large river dam regulation on bacterioplankton community structure. FEMS Microbiol. Ecol. 84 (2), 316, 2013.

28. MUKKATA K., KANTACHOTE D., WITTAYAWEERASAK B., TECHKARNJANARUK S., BOONAPATCHAROEN N. Diversity of purple nonsulfur bacteria in shrimp ponds with varying mercury levels. Saudi J. Biol. Sci. 23 (4), 478-87, 2016.

29. YURKOV V., CSOTONYI J.T. New light on aerobic anoxygenic phototrophs. in: The purple phototrophic bacteria, Springer Netherlands, 31-35, 2009.

30. TAKAYANAGI A., TAKAHASHI S., NISHIDA $H$. Requirement of dark culture condition for enlargement of spheroplasts of the aerobic anoxygenic photosynthetic marine bacterium Erythrobacter litoralis. J. Gen. Appl. Microbiol. 62 (1), 14, 2016.

31. ESTEBAN D.J., HYSA B., BARTOW M.C. Temporal and spatial distribution of the microbial community of Winogradsky Columns. Plos One, 10 (8), e0134588, 2015.

32. SOGIN M.L., MORRISON H.G., HUBER J.A., WELCH D.M., HUSE S.M., NEAL P.R., ARRIETA J.M., HERNDL G.J. Microbial diversity in the deep sea and the underexplored "rare biosphere". P. Nat. Acad. Sci. 103 (32), $12115,2006$.

33. ODA Y., LARIMER F.W., CHAIN P.S., MALFATTI S., SHIN M.V., VERGEZ L.M., HAUSER L., LAND M.L., BRAATSCH S., BEATTY J.T., PELLETIER D.A., SCHAEFER A.L., HARWOOD C.S. Multiple genome sequences reveal adaptations of a phototrophic bacterium to sediment microenvironments. P. Nat. Acad. Sci. 105 (47), 18543, 2008. 
34. ZENG Y., SELYANIN V., LUKEŠ M., DEAN J., KAFTAN D., FENG F., KOBLÍŽEK M. Characterization of the microaerophilic, bacteriochlorophyll a-containing bacterium Gemmatimonas phototrophica sp. nov., and emended descriptions of the genus Gemmatimonas and Gemmatimonas aurantiaca. Int. J. Syst. Evol. Micr. 65 (8), 2410, 2015.

35. ZENG Y., FENG F., MEDOVÁ H., DEAN J., KOBLÍŽEK M. Functional type 2 photosynthetic reaction centers found in the rare bacterial phylum Gemmatimonadetes. P. Nat. Acad. Sci. 111 (21), 7795, 2014.

36. ZENG Y., BAUMBACH J., BARBOSA E.G., AZEVEDO V., ZHANG C., KOBLIZEK M. Metagenomic evidence for the presence of phototrophic Gemmatimonadetes bacteria in diverse environments. Environ. Microbiol. Rep. 8 (1), 139, 2016.

37. MEDOVA H., BOLDAREVA E.N., HROUZEK P., BORZENKO S.V., NAMSARAEV Z.B., GORLENKO V.M., NAMSARAEV B.B., KOBLIZEK M. High abundances of aerobic anoxygenic phototrophs in saline steppe lakes. FEMS Microbiol. Ecol. 76 (2), 393, 2011.

38. KOMPANTSEVA E.I., KOMOVA A.V., SOROKIN D.Y. Communities of anoxygenic phototrophic bacteria in the saline soda lakes of the Kulunda steppe (Altai Krai). Microbiology, 79 (1), 89, 2010.
39. FENG Y., LIN X., MAO T., ZHU J. Diversity of aerobic anoxygenic phototrophic bacteria in paddy soil and their response to elevated atmospheric $\mathrm{CO}_{2}$. Microb. Biotechnol. 4 (1), 74, 2011.

40. CSOTONYI J.T., SWIDERSKI J., STACKEBRANDT E., YURKOV V. A new environment for aerobic anoxygenic phototrophic bacteria: biological soil crusts. Env. Microbiol. Rep. 2 (5), 651, 2010.

41. FERRERA I., SARMENTO H., PRISCU J., CHIUCHIOLO A., GONZALEZ J.M., GROSSART H.P. Diversity and distribution of freshwater aerobic anoxygenic phototrophic bacteria across a wide latitudinal gradient. Front. Microbiol. 8, 175, 2017.

42. SALKA I., CUPEROVA Z., MASIN M., KOBLIZEK M., GROSSART H.P. Rhodoferax-related pufM gene cluster dominates the aerobic anoxygenic phototrophic communities in German freshwater lakes. Environ. Microbiol. 13 (11), 2865, 2011.

43. KIM M.K., SCHUBERT K., IM W.T., KIM K.H., LEE S.T., OVERMANN J. Sphingomonas kaistensis sp. nov., a novel alphaproteobacterium containing pufLM genes. Int. J. Syst. Evol. Micr. 57 (7), 1527, 2007. 